\title{
The Influence of Terrorism Activities on Muslim-Christian Relations in Garissa County, Kenya
}

\author{
Abdi Aden Ismail', Newton Kahumbi Maina ${ }^{2}$, Margaret Gecaga ${ }^{3}$ \\ ${ }^{1}$ Masters of Arts student, Department of Philosophy and Religious Studies of Kenyatta University, \\ Kenya. Email abdiaden.fatah@gmail.com \\ ${ }^{2,3}$ Department of Philosophy and Religious Studies, Kenyatta University, Kenya
}

ABSTRACT

Terrorism is no doubt a global problem of the $21^{\text {st }}$ century and as evidenced by the continued terror attacks, the menace is causing major global security distress. In Kenya terrorism has among other things considerably affected the Muslim-Christian relations in the country. Despite vast literature on terrorism and interreligious relations, there are limited research on the influence of terrorism on Muslim-Christian relations in Garissa County, Kenya hence this study. The general objective of this study was to examine the influence of terrorism on Muslim-Christian relations in Garissa County, Kenya. The study employed both descriptive and explanatory design. The target population of the study was 199,469 from Garissa County from which a sample of 384 respondents were obtained through purposive sampling. Data was collected from primary sources using; questionnaires, interview guide and focus group discussions as well as secondary sources, through literature review. The findings revealed that, terrorist selective attacks of Christians and the use Islamic concept of jihad during attacks have created suspicion and mistrust among the Muslims and Christians in the area. The study concludes that unless the misunderstanding of the concept of Jihad is demystified, the Muslims-Christians relations will significantly be affected as the terrorist will continue propagating their attacks as an Islamic concept of jihad. The study recommends that Muslim leaders needs to demystify the concept of Jihad in order to restore Muslim-Christian relations. Also, the Government security agencies and civil society, Muslim leaders, and Christians should continually organize awareness campaigns in the region to create alertness about the terrorist's schemes.

Key Words: Al-Shabaab, Influence of Terrorism, Jihad Teaching in Islam, Muslim-Christian relations, Perpetrator Characteristics

DOI 10.35942/ ijcab.v6i1.223

\section{Cite this Article:}

Ismail, A., Maina, N., \& Gecaga, M. (2022). The Influence of Terrorism Activities on MuslimChristian Relations in Garissa County, Kenya. International Journal of Current Aspects, 6(1), 1-23. https://doi.org/10.35942/ijcab.v6i1.223

\subsection{Introduction}

There is no universally agreed definition of the term terrorism (Schmid,2011, p.39). In this study, the term refers to any criminal act, such as violence against civilians that results in deaths or significant physical injuries, or the kidnapping of hostages, with the goal of spreading terror in the larger populace for political or religious reasons. Terrorism and terror related activities have been of global concern in this century. Due to the increased activities of terrorists the menace has been referred to as the $21^{\text {st }}$ century threat to civilization (Anangwe, 2004, p.86). Incidents of terror 
attacks including suicide bombings, improvised explosive devices, grenade attacks, and hijacking of airplanes by terrorist groups have become a common happening in the world. These activities have resulted to deaths and suffering of many innocent lives and loss of unimaginable amount of wealth.

Kenya has recently been the target of terrorist attacks, most of which mainly attributed to AlShabaab terrorist group. Nearly a quarter of the group's assaults (22.7 percent) occurred in Kenya by 2012 (Start, 2013, p.1). The $21^{\text {st of }}$ September 2013 Westgate Mall attack in Nairobi which left 70 people dead is the first hostage-barricade attack by terrorist group like Al-Shabaab in Kenya (Start 2013, p. 4). Since then, grenade attacks, bombings and killing of innocent people have been occurring repeatedly in various parts of the country. For instance, on March 31, 2014, six people were killed in an explosion in Nairobi's Eastleigh suburb (Daily Nation, 2014, March 19). On April 24, 2014, four people were killed in a car explosion at Nairobi's Pangani estate. On June 16, 2014, a deadly attack in the coastal city of Lamu left close to fifty people dead and dozens of others injured. This attack was claimed by Al-Shabaab militants in Somalia as retaliation for the killing of Muslim clerics in the coastal town of Mombasa (Aljazeera, 2014).

The country's North Eastern County of Garissa has had its fair share of the terror attacks. The region has suffered from frequent attacks and kidnappings conducted by Al-Shabaab terror group. This hAs a resulted in the death of many people both Muslims and Christians and loss of property. For example, on November 16, 2011, a grenade attack in Garissa town's East African Pentecostal church killed two people (Star, 2012, August 7). On 1 July, 2012, gunmen attacked two churches simultaneously in Garissa town leaving seventeen people dead (Star, 2012, July 2.). On January 4, 2013, two people were killed in a grenade attack at Dagahley (Standard, 2013). And on January 16, 2013, suspected Al-Shabaab militants killed five people in a restaurant in Garissa town. At least nine people were also killed on April 18, 2013 in Garissa Holiday Inn Hotel (Star, 2013, April, 20). On April 2, 2015, the worst of all attacks in Garissa left close 150 people dead at Garissa University College.

Al-Shabaab has been justifying their attacks in Garissa as a Jihad, and holy war against nonMuslims. The group have developed certain common characteristics (perpetrator characteristics) which they use to justify their heinous acts. This includes among others characteristics, the use of Islam as a legitimization tool for their illegal activities. As a result the terror groups have mainly selectively targeted Christians and their worshiping places as well as their business premises. This selective tendency of the terrorist groups has caused suspicions and almost sparked off religious conflict between Muslims and Christians in Kenya (Daily Nation, Nov 13, 2012). Starting from the 2013 Nairobi West Gate Mall attack for instance, Al-Shabaab terrorist group have selectively targeted and consciously attacked the non-Muslims (Maina, 2017, p.22). These selective tendencies have exacerbated suspicion between Muslims and Christians in the county leading to the creation of negative attitudes towards Islam and Muslims. This has led to the perception that Islam is a terrorist religion and that the perpetrators of terror attacks are Muslims. It is against this backdrop that this research was carried out to bring to light the influence of terrorism on MuslimChristian relations in Garissa county, Kenya.

\subsection{Research Problem}

Although, religious relations play a significant role in nation's well-being, terrorist activities are seen as likely impediment of peaceful Muslim-Christian relations in Garissa County, Kenya. The association of terror attacks with Islamic principles such as Jihad and terrorist selective attacks of 
Christians and their worshiping places could polarise the Muslim-Christian relations in Garissa County. Consequently, stalling the county development agendas. So, a thorough understanding of the nature of terrorism and the scope of its consequences on Muslim-Christian relations is required. Despite immense empirical literature on terrorism and its association with religious relations, much less is known about the impact of terrorism on Muslim-Christian relations. More specifically, the influence of terrorism on Muslim- Christian relations in Garissa County, Kenya is yet to be adequately documented a knowledge gap this study endeavoured to fill.

\subsection{Objective of the Study}

The main objective of the study was to explore the influence of terrorism on Muslim-Christian relations in Garissa County-Kenya.

The specific study objectives were;

i. $\quad$ Examine the teaching of Islam on Jihad.

ii. Assess the effect of perpetrator characteristics on Muslim-Christian relations in Garissa county.

iii. Discuss the Muslim-Christian relationship in Garissa County.

\subsection{Literature Review}

\subsection{Theoretical Framework}

The study was anchored on the Religious Utilization and the Game theories as the most relevant theories for the current study.

\subsubsection{Religious Utility Theory}

The central point of the religious utility theory as fronted by Cavalho (2020) is on the importance of religion where individuals are given a feeling of significance and belonging, which allows terrorist groups to use religious doctrines and institutions to entice others to join their cause. Cavalho (2020) contends that, some of the reasons for joining terrorism is informed by social and cultural disruptions in societies. Problems such as family break ups, dislocation and alienation of individuals from the family social fabrics and lack of belongingness drives them to join terrorism. This subsequently provides fertile grounds for terrorist recruitment of the socially alienated individuals who are in search for meaning and belongings (Cavalho2020). As opined by Cinoglu (2010), the terrorist groups, claim that their deeds and ideologies to be the cure for these alienations. They purport that their course will provide an alternative solution to the exploitative nature of society that creates alienation (Cinoglu 2010).

Cavalho (2020), highlights that, terrorist groups face many challenges to accomplish their goals. These challenges among others include, getting recruits, evading of security agencies' monitoring, discovery and their penetration. To overcome these barriers, terrorist organizations must utilize religion as a justifying tool for their actions. Terrorist groups as Cinoglu (2010) points out, will interpret ideal religious value systems in ways that are fundamentally contrary to mainstream teachings. As a result, their version of Islam must be read differently from the mainstream Islam in order to justify their crimes. Furthermore, the nature of terrorist attacks needs individuals who are dedicated and driven to participate in extreme violent activity (Cinoglu 2010). New recruits are put through intense training sessions to indoctrinate them with new interpretations of religious concepts, values, goals, and methods, among other things (Cinoglu 2010). As a result, terrorist 
cells incubated in such conservative religious groups have lower rates of defection and are more difficult for security agencies to follow and penetrate.

Al-Shabaab attacks in Garissa County has been characterized with the use of Islam both as legitimizing tool for violence and as an avenue for recruitment and raising funds for their missions. The group also use Islamic religion according to their version of interpretations to select targets. It is therefore from this backdrop that the religious utility theory is considered relevant to the current study. The theory helps to put in to perspective and explain terrorist behaviours of misinterpreting Islamic concepts such as Jihad to further their illegitimate goals. This will be relevant to the study in examining the teaching of Islam on Jihad. It will also be relevant to the study in assessing the effect perpetrator characteristics on Muslim-Christian relations.

\subsubsection{Game Theory}

The Game theory as fronted by Harvey Lapan and Todd Sandler (1988) and revised by Sandler and Daniel Arce (2003), involves influencing the action and counter action of interacting parties that is; terrorist attacks and government counter terrorism measures. The main player of the game theory are the terrorist and governments and each one of them tries to get maximum benefit towards its goal (Lapan and Sandler, 1988). According to Sandler and Arce (2003), players in the game will strive to act and respond in the same way that they believe their opponents would act and react. That the terrorists' decisions and activities are affected by the governments, and vice versa (Sandler and Arce 2003). As per Sander and Arce (2003), governments' anti-terrorism measures are either proactive or reactive. Proactive strategy entails aggressively chasing terrorists and eliminating their resources, infrastructure, and workforces through direct engagements. Reactive policy on the other hand involves defensive actions aimed at either diverting terrorist attacks or reducing its damages. Proactive antiterrorism strategy may include measures such as pre-emptive attacks like airstrikes against terrorist groups in their hideouts. Similarly, reactive policies may include measures such as protective actions like strengthening internal defensive mechanisms devised by terror prone governments (Sander and Arce, 2003).

The suitability of game theory involves the probability of knowing terrorists' choice of targets where they always pick targets with the highest expected payoff for their attack so as to maximize its benefits (Sander and Arce, 2003). Further, the rationality of actor's behaviours and predictability of their probable actions and reactions has been identified as a central principle of the theory in explaining the terrorism phenomenon. For instance, as pointed out by Enders, \& Sandler, (1995), in the 1970s following the high number of airplane hijackings, governments introduced metal detectors at airports, subsequently leading to relative increase to the cost of hijackings for terrorists. However, to counter this development, the terrorists changed their tactic from hijackings to kidnappings. As Lapan and Sandler (1988) points out the theory helps in decision such as when and if a government should admit to terrorist demands. The Game theory is seen as an appropriate tool to explain and understand the terrorism phenomenon in Garissa county, Kenya. Terrorist actors such as Al-Shabaab are capable of acting rationally based on government actions. It is on this basis that the study used this theory to analyse terrorism and its effect on Muslim-Christian relation in Garissa county. The theory enabled the researcher to hypothesize and explain why Al-Shabaab is increasingly attacking the county and by extension Kenya. Also, by showing the tactic(s) used by the terrorist in justifying their attacks, the Game theory is indispensable tool to explain why for instance Al-Shabaab capitalizes on target selection by 
attacking Christians and their worshiping places thus enriching the study to analyse the impact of Al-Shabaab target selection on Muslim-Christian relation.

\subsection{Empirical Literature Review}

\subsubsection{Islamic Teaching on Jihad and Terrorism}

Kingsley (2010, p.554) opines that many scholars mostly of western orientation blame religion for terrorist-related activities perpetrated across the globe. He posits that, Islam has in particular been the biggest victim of these blames as the main architect of religious violence of terrorism. Saighal, (2003 as cited by Kingsley) further says that, Muslims are the reason for pushing their communities into violent practices that pose challenges to the harmony of the universe and perpetrating the backwardness of their community. Aktan, (2006, p.26) on the other hand, argues that Islam as religion is not to blame for the global terrorism. On the contrary, he believes that it is the misapplication of the Islamic concept of Jihad as a justification phrase by terrorist organisations and individuals involved in terrorist activities that has led to people wondering about a link between terrorism and Islam. Informed by the above literature review, this study therefore will endeavour to examine the extent to which relationship between Christians and Muslims in Garissa is affected using Islamic teaching by terrorist groups in conducting their attacks.

Islamic teachings on war and peace and the whole concept of Jihad have been surrounded by a lot of controversies and misconceptions in both the Islamic and the non-Islamic world. Hassan (2013) argues that, there is need for an impartial discussion in this regard as much work so far has either been confined to historical contexts or plagued by subjective propositions and personal opinions. From the above views, one may conclude that Islam is the worst culprit of the global terrorist attacks. However, such postulations call for the knowledge of the actual teachings and position of Islam on the phenomenon of terrorism and clarification between terrorism and Jihad. This study was conducted to fill this gap of information and demystify misconceptions about Jihad and terrorism in Islam. Most of scholars, Noorani (2002), Ahmad (2002), Mazrui (2006), Gulen, (2010) Hassan (2013) \& Kurucan (2013) agree that in Islam, the term Jihad basically means to struggle or to strive so as to achieve good and avoid worldly evil deeds or striving towards achieving Allah's blessing and struggling against His Wrath-Hellfire. Jihad, according to Noorani (2002), Ahmad (2002) and Kurucan (2013) can be conceptualized as consisting of two dimensionsphysical and spiritual dimensions or the minor and the major Jihad respectively. The physical dimension involves external actions and includes waging war in defence or for attaining peace. Spiritual dimension of Jihad deals with internal struggle of a Muslim in the fight against temptations of sin and being on the right path.

Also, according to Ahmad (2002), Mazrui (2006) Gulen, (2010), Kurucan (2013) \& Hassan (2013), the greatest Jihad is the internal Jihad, in which one struggles to contain his/her soul against worldly forbidden temptations of sin such as killing, stealing, failing to pray, backbiting, extramarital sex, oppressing the poor, drinking alcohol etc. The physical dimension is a minor or lesser Jihad and is not a priority. It can be achieved by fulfilling the Greater Jihad. Jihad cannot be equated to mean war. The Holy Qur'an has alluded to words like 'Fitna', 'Fasad' and 'Qital' or war itself when referring to war (Shah, 2009). For, Jihad the Qur'an has used the term "Qital Fi Sabill-i-Allah" - an armed struggle for the cause of Allah. The Quran states clearly "Not all people will believe' (Albayrak, 2010, Hassan, 2013). On the contrary, Jihad has been a religious reference point of many terrorists to justify atrocities against innocent lives. So, what is motivating these terrorists? Could there be another way of interpreting the Qur'an and the Prophet's Ahadith? What 
is blinding the terrorist from seeing these verses and Ahadith? Through examining the teaching of Islam on Jihad, this study attempted to find out answers to these questions to fill the knowledge gap as will comprehensively be discussed later in chapter four of the study.

According to Mazrui (2006) the term "terrorism" is a new word but the phenomenon of deliberately killing innocent civilians is not new in world history. He says that, although, none of the major world religions explicitly talk about terrorism as known to many today, Islam more than any other religion clearly gives guidance on the treatment of women, children and non-combats in war zone. Islam prohibits transgression during war and does not allow civilians and noncombatants to be killed. "Transgression" for Albayrak (2010), is understood by scholars as killing civilians, torturing the enemy's soldiers, not respecting the dead bodies of the enemy, not meeting the basic needs of the enemy prisoners and not obeying the rules of war. However, Gulen (2010) posits that in this era of terrorism, Islam has been the victim of accusation of either condoning terrorism through its teachings or its followers perpetrating the act. As a result, the common problem of terrorism has become almost synonymous with Islam and Muslims, and thus Muslims are quickly categorized as 'them' (Albayrak, 2010, p.133).

Mazrui (2006) admits that any person has the potential of committing a terror activity as a way of seeking redress for any wrong committed against the person, however, if the person is a Muslim, there is more condemnation and publicity. In this context, most people associate terrorism with Muslims who happen to be most people seeking redress against wrongs committed against them. Mazrui (2006) further opines that the accusation against Muslims has particularly emanated from the non-Muslim world. Misunderstanding on Jihad as a concept in Islam has greatly contributed to this kind of attitude (Shah, 2009). The present study further endeavoured to fill the gap of knowledge on how misconception about Islam and its teaching on Jihad that is prevalent among the communities living in Garissa County is being exploited by the terrorist and is inadvertently influencing the Muslim-Christian relation.

Terrorism in Kenya affects both Muslims and non-Muslims whether directly or indirectly (Maina, 2017). But the erroneous use of Islam by terrorists in justifying their activities creates an impression that terrorism is synonymous with Islam, which further contributes to suspicion and conflict in the relations between Muslims and Christians in the country. Through examining the Islamic teaching on Jihad as well as assessing the effects of perpetrator characteristics on MuslimChristian relations, this study aimed at filling a gap of information among many Kenyans and particularly residents of Garissa County both Muslims and non-Muslims, that Islam does not condone acts of terrorism. Suicide bombing and attacking of crowds with bombs as well as killing of oneself and kidnapping civilians is not allowed in Islam. "And do not murder yourself; God is kind to you," Allah declares in the Quran. Whoever does so out of enmity and violation, we will toss him into the flames, which is a simple task for God" (4:29-30). Noorani (2002), on the other hand, focuses on the few instances in which the Quran calls for battle (Quran, 2:190, 60:8-9). However, in these cases, Muslims are only permitted to conduct war if they are oppressed and subjected to violence. Thus, war is only for defensive purposes (Aktan,2006, p.28). More importantly, under these situations Muslims are warned against the use of unnecessary provocation or violence, attacking of worshiping places, murder of women and the elderly (Aktan,2006, pp.2830). Considering the teachings of Islam against killing innocent people, this study therefore sought to determine the terrorist groups justification of carrying out terrorism in the name of Islam. 
It is clear from the review above, that neither the Quran nor the prophetic traditions condone terrorism. Killing a person is equated to killing the whole humanity in the universe. Thus, it is not only Muslims whose killing is forbidden but Allah has also made it a grave sin to kill a soul whether Muslim or non-Muslim in an unjustified way. Suicide and killing of oneself is equally prohibited in Islam. War is accepted in a limited circumstance of self-defence and in these instances strict regulation has been laid by both Allah in the Quran and the Prophet through his tradition. As pointed by Hassan (2013), there is neither command nor justification in the Quran or the Sunnah of the Prophet to murder and massacre innocent people under any circumstances whatsoever. Despite the Islamic teaching on jihad and its promotion for peaceful coexistence, terrorist groups such as Al-Shabaab have been using Islamic religion's concept of Jihad in justifying their activities. It has consequently contributed to incorrect perceptions by both Muslims and non-Muslims about Islam in Kenya. As a result, this study attempted to explain these incongruities through the use of the available theories on the subject to bring out the interplay between terrorist activities and Islamic teaching of Jihad in Garissa county.

\subsubsection{Effect of Perpetrator Characteristics on Muslim-Christian relations}

Evidence shows that terrorist groups display several common characteristics (henceforth perpetrator characteristics) to justify their violent behaviours. As pointed by Borum (2004), terrorist groups constantly invoke myriads of accusations and grievances toward their adversary as a justification for violence and to "make the victim targets appear culpable, provocative, and unsympathetic" (Borum, 2004, p.51). Further, as pointed by Borum (2004), they use ideologies that cast their adversaries in a dehumanized term by either through a comparison with impure and unpleasant animals such as pigs, watch dogs or actually demonizing them. Demonization according to Berlet, (2004) as cited by Borum "fuels dualism-a form of binary thinking that divides the world into good versus evil with no middle ground tolerated" in essence, "is a death sentence imposed on the adversary" (Borum, 2004 p.52). Holbrook and Horgan (2019) also share Borum's postulations that perpetrator characteristics include "a collection of grievances, the identification of a culprit responsible for grievances, and arguments favouring terrorist acts for the community and individual" (P.6). Similarly, Carvalho (2020, p.1) points out that terrorist groups operate within a religious ecology because of the utility of religion to individuals. He contends that religion is exploited as a justification tool by terror groups to legitimize their illegal activities and as an avenue for recruitment and incubation of more extreme groups.

Carvalho (2020, p.11) further explains that; it is the usefulness of religion in providing meaning and belonging to large numbers of people that attracts terrorist groups to create a connection between violent acts and individual faiths. This among other things, helps to elicit costlier sacrifices such as suicide bombings "even when these actions run counter to the actor's moral convictions" (p.11) Aktan (2006, pp 26-27) points out that, terrorist organisations must use religious teachings to persuade their militant members to commit acts of terror. Hussain and Madhany, (2008) further opine that terrorists quote verses from the religious texts, such as the Quran, to justify their claims. They in particular cite and misinterpret verses on Jihad to advocate for the use of violence against civilians to address their grievances (Hussain and Madhany, 2008) These verses are often taken out of context, to intentionally twist their meaning so as to advance their illegitimate activities. Eventually, this results in people speculating a relationship between terrorism and Islam. This has in particular created a perception among the Christians in Kenya that Islam is a violent religion (Maina, 2017) and that Muslims are fundamentally required to be violent. 
From the foregoing review, it is clear that terrorist groups such as Al-Shabaab portray a similar cross cutting perpetrator characteristic to give their course a justification and legitimacy to woo sympathy and support from the larger community. Apparently, Al-Shabaab activities and behaviours in Kenya fit in well in to the above illustrated description of perpetrator characteristics. From the use of Islam as a justification tool, to display of myriads of accusations and grievances against Kenyan government as a cause for their attacks in the country, the terrorist group develop a rallying cause for their activities. For instance, in almost all the post 2011 Kenya Defence Forces (KDF) invasions of Somalia's terrorist attacks in Kenya, Al-Shabaab claimed them to be revenge for the presence of Kenya's troops in Somalia (Lind et al., 2015, Nyongesa,2017). The attacks were therefore as a result of accusation against KDF presence in Somalia and demanded for their withdrawal through administration of attacks. These perpetrator characteristics as displayed by terrorist to further their goal, influences the Muslim-Christian relation in many ways. For instances by demonizing and selectively attacking a particular religious section of a given community the terrorist intends to instill violence pitting one faith group against the another. This was well demonstrated by Al-Shabaab terror group when they for instance, staged a twin attacks of two churches in Garissa on $1^{\text {st }}$ July 2012, that left about 17 people most of them Christian worshipers dead. (Maina 2017). They often used the term Kuffars (Arabic term for non-believers) and in the 2015 Garissa university attack they selectively killed Christians (Aguilar 2016). Although, AlShabaab terrorist group portrays all behaviours of Perpetrator characteristics, there is limited studies that tries to vividly bring out and explain the interlink between these perpetrator characteristics and terrorist attacks in Garissa county a gap this study attempts to fill.

\subsubsection{Muslim-Christian Relations in Garissa County}

Hargis (2012) says that although, Kenyans have frequently fought over political and economic resources along tribal lines and influences, the country has a long history of religious coexistence compared to some other parts of the world. Muslims and Christians have lived together in relative peace for a long period in the country. However, the terrorism phenomenon has changed this perspective and religious tensions are now a central concern of the Muslim-Christian relations in Kenya (Berkeley Centre, 2017). Several events of terrorism have brought dormant MuslimChristian issues to the fore. The killing of over 200 people in the1998, American embassy attack in Nairobi, the 2002, terrorists attempted shoot down of a passenger jet carrying Israeli tourists which was followed by a suicide bombing against a hotel near Mombasa (Amsalem \& Kunaal, 2018) and the continuous Al-Shabaab attacks in the country has painted a dull picture of MuslimChristian relations in Kenya. Although, Muslims in the country have equally been victims of terror attacks, Maina, (2017, p.21) argues that, the Christians view themselves as the main target of the terrorist groups. This is mainly affirmed by the terrorist tendency of selectively attacking Christians and their worshiping places. Such targeted attacks were mainly evident in 2012 when Al-Shabaab attacked two churches in Garissa town and killed 17 people and 40 others injured (Maina, 2017, p.21). The terrorist targeted and selective attacks is no doubt creating deep rifts between Muslims and Christians in Kenya (Maina, 2017, p.23).

Similarly, the Counter-Terrorism war has exacerbated the Muslim-Christian relation in Kenya. According to Naado (2013), the Kenyan Government approach and response to the terrorism is becoming a threat to the peaceful Muslim - Christian relations in the country. Naado (2013) says that when it comes to the fight against terrorism, Muslims feel discriminated and deprived of their basic human rights. He points out that, mysterious killing of Muslim clerics, indiscriminate arrests and detention of Muslims suspects without proper investigation and prosecutions, raiding of 
mosques by security personnel as well as extradition of terror suspect to foreign countries is seen by many Muslims as direct target to the community (Naado 2013)

A report released by Open Society Foundations similarly attests to the mistreatments of Muslim terror suspects by Kenya's Anti-Terror Police Unit (ATPU). This was mainly evident in Mombasa, Nairobi among other towns where in the years of 2010 and 2012 Muslims were constantly harassed without proper investigation and prosecution. Some of them were renditioned to Uganda against the ruling of the Kenya's courts (Open Justice Foundation, 2013). In response to military operation conducted in Garissa town following a terrorist attack that left three Kenya Defense Forces (KDF) soldiers dead in November 2012, Farah Maalim then deputy Speaker of Kenya's $10^{\text {th }}$ Parliament stated that during the operation women had been raped, schoolchildren shot in the town, "yet this was happening because of the failure of the Government to track down suspected Al-Shabaab members" (Standard, 2012, Nov.21). From the foregoing literature review we can deduce that, Kenyans have not fought on religious lines. Followers of the different religions have since independence coexisted peacefully. However, the terrorist selective strategy of attacking some religious holy places and killings of particular believers is creating enmity and suspicion between the Muslims and Christians. Also, the Government approach in handling the terrorism menace is seen by some sections of Muslims as discriminatory and targeting only the Muslims in the country. For example, the mysterious killing of Aboud Rogo in 2015 is perceived by some Muslims as an act of extrajudicial killings by the government targeting Muslims (ICG, 2012, Chome,2016). Collective punishment of the Muslim community by the security apparatus after terrorist attacks in the country as witnessed in Garissa town in the past clearly affirms the Government's skewed approach of handling the threat (ICG, 2012).

However, the researcher notes that although numerous literature on Muslim-Christian relation in Kenya has been written, they largely focus on the effect of issues such as; marginalization, political, social-cultural, and historical grievances on Muslim-Christian relation. This is evident in the works of Chande, (2008), Mahmoud, (2008), Ndzovu, (2014), Alio, (2015), Cannon, (2016) and Moywaywa, (2018). Among the few who attempted to bring out the effect of terrorism on Muslim-Christian relation albeit in the larger Kenyan context include Maina (2017). As a result, studies on the effect of terrorism on Muslim-Christian relation in Kenya and particularly in Garissa county is sparse. The current study therefore through discussing the effects of terrorism on Muslim-Christian relations in Garissa County attempted to fill this gap of knowledge as will be presented later in the findings in chapter four.

\subsection{Research Methods}

The study was conducted in Garissa county, Kenya and used descriptive and explanatory research design to describe and understand the influence of terrorism on Muslim-Christian relation in the area. The study targeted population was 199, 469 consisting of religious clerics both of Muslims and Christian faith, youths and security personnel. Out of this population a sample size of 384 respondents were drawn through purposive sampling methods. The 384 sample was informed by Mugenda and Mugenda (2003) which suggests that if target population is more than 10,000 a sample size of 384 is preferred hence the choice of the sample size. Out of the 384 respondents a specific number of 37 security personnel were purposively drawn from the six different sub counties in Garissa and the different subdivisions of the security sector. Also 38 religious clerics were also drawn from different Islamic institutions such as mosques, the Khadi courts and Muslim organisations such as Supreme Council of Kenya Muslims (SUPKEM). 
The purposive choice of these particular groups' samples was informed by various factors. First, the choice of the youth was mainly due to their large numbers in the study area's population and their high level of unemployment (Garissa county government, 2019,) which contributes to their vulnerability to radicalization and recruitment by the terrorist groups. Thus the researcher deemed their views indispensable in finding out the causes of terrorism in the study area. Data from the clerics on the other hand was necessary due to their roles and technical knowledge on; religious coexistence, religious teachings on matters of war and peace as well as information on terrorism and its causes in the study area. Finally, the choice on security officers was informed by their dayto-day professional engagements on security matters. Thus making them the most relevant people to give information on matters of security more so, terrorism and its causes as they handled information relating to terrorism as part of their duties. The study used questionnaires, interview guides and FGDs as data collection instruments.

Data sampling, classification, and analysis were carried out in order to produce clear, understandable, up-to-date, genuine, and reliable information aimed at achieving the research study's objectives (Gupta \& Rangi, 2014). The obtained data was rigorously scrutinized and verified for inaccuracies before being tallied. The study used qualitative data analysis methods to analyze qualitative data (from interviews and focus groups), while quantitative data (from closedended questions) was analyzed using quantitative data analysis methods. The qualitative analysis approach was used to analyze data by categorizing and organizing it into themes, with the goal of obtaining actual, rich, and deep data that would be conveyed in narrative form. As a result, qualitative data was analyzed using themes (thematic analysis) and in accordance with study indicators (Creswell, 2014). In addition, documents relevant to the impact of terrorism on MuslimChristian relations in Garissa County were examined using qualitative content analysis. Descriptive statistics were employed to assist the researcher comprehend and evaluate the study's implications by establishing patterns, trends, and linkages. Among the information representations employed were figures, tables, and narratives. In descriptive statistics, the mean, standard deviation, frequencies, and percentages were used to analyze the data trends. The Statistical Package for the Social Sciences (SPSS) version 23 was used to investigate this.

\subsection{Research Findings}

\subsection{Teaching of Islam on Jihad}

The results obtained from the majority of the respondents on this objective indicated that Islam provides teachings on Jihad. The findings established that, Jihad is a teaching in Islam that is enshrined in the Qur'an and prophetic traditions. The respondents largely agreed the term Jihad is derived from the Arabic word Mujahada and Juhdi which means to work or strive hard. Further, the aim of Jihad is to achieve Allah's reward of heaven (Janah) and be saved from His wrath and hell fire (Nar). It entails telling others the right thing (Amr bil-ma'ruf) and discouraging against wrong deeds (Nahyi 'ani Munkar) as well as propagating Islam (dawah) to non-Muslim. Also, the findings' descriptions of Jihad indicate that Muslims should act in a manner that is holy through striving hard to please Allah in doing the right and avoiding the wrong things. It is obligatory for every Muslim to strive hard (to do Juhdi) and fulfil his/her religious obligation for the cause of Allah so as to attain His paradise. This is also affirmed by the Quran in which Allah says; "I did not create the Jinns and human beings except for the purpose that they should worship me" (Quran, 51:56). Allah in this verse require every human 
being to constantly do that which pleases Him and avoid that which displeases Him. The study also revealed there are two forms of Jihad: -the greater Jihad and lesser Jihad.

The greater Jihad (Jihad-al-Nafsi) involves struggle with one's own soul, through restraining against; his/her passions and against doing wrong things such offending others, backbiting, stealing, killing, drinking alcohol and the like. The greater Jihad also involves struggle towards doing the religiously laid rightly obligations and activities such as praying, helping the poor, maintaining peace with neighbours, fasting, performing pilgrimage to Makah (Noorani, 2002, Mazrui, 2006, Gulen, 2010a; Hassan, 2013, Kurucan, 2013). Carrying out the greater jihad (Jihad-al Nafsi) is a constant and has no limit of time and place and is required from all mature Muslims who are of sound mind. The lesser form of Jihad in Islam on the other hand, is a physical form of struggle that entails Muslims engagement in war with enemies mainly against oppressions meted on them. This is evident in the Quranic verse in which Allah says; "Permission to fight is given to those against whom war is made, because they have been wronged and Allah indeed has power to help. Those who have been driven out from their homes unjustly only because they said, Our Lord is Allah...Quran, 22: 39-40."

The lesser Jihad has a laid down strict rules and procedures and has time limit as well as conditions. This form of jihad must be for the cause of Allah and should not be for achieving personal goals. Further, it should not be a sudden decision, that one just decides to attack or not to attack people of other faiths. Allah says, "And fight in the way of God those who fight you, but do not commit aggression. God loves not the aggressors" (Quran 2:190). During engaging in war the prophet used to advice Muslim commanders to "Fight in the name of Allah and to fight only those who (engages them in combat) from among the disbelievers and not exceed their limits, not to misbehave, betray, deface the dead bodies and not to kill children and the elderly." The findings clearly show that Jihad in Islam is not for terrorizing people. More so, the lesser Jihad is not for propagating terrorism and violence and that war should only be resulted to for defensive and not offensive.

However, the study established that the principle of Jihad in Islam is largely misunderstood as only waging war against non-Muslims. It is also misused by terrorist groups such as Al-Shabaab to rally support and justify violent actions. These findings also resonate with other studies by Mazrui (2006) and Gulen (2010). For instance, Gulen (2010), opines that it is the misuse of Jihad by terrorist groups that has contributed to accusation and victimization of Islamic religion as either condoning terrorism through its teachings or its followers perpetrating the act. Mazrui (2006) further opines that the accusation against Muslims has particularly emanated from the non-Muslim world. Misunderstanding on Jihad as an Islamic concept has greatly contributed to this kind of attitude.

It is important to point out that, both the primary and secondary sources of the study agree that, Islam teaches its followers to conduct themselves and coexist with others in a peaceful environment. Muslims are supposed to carry out their religious obligations of calling others to Islam (dawah) in a peaceful and in a manner that do not offend people of other faith. Islam does not allow Muslims to force others to profess the Islamic religion but obligates them to propagate and tell others about the teachings of their religion. It is not the responsibility of the Muslims to make others accept Islam. Muslims are always supposed to be ambassadors of peace and not warmongers. They are required to explore all avenues of solving any misunderstanding in harmony. However, in the event their rights to worship are denied or places of worship attacked, 
it is acceptable for them to fight back. Equally, defending their land and property against aggressors who unjustly invades and forcefully acquires them is accepted as well. Even in the circumstances where it is seen that engagement in war with non-Muslims is inevitable, the permission and the order has to be given by a Muslim ruler (Amir). Further, in the circumstances of war, the Quran provides clear guidance on the circumstances and the conditions for war. Allah says; "Permission (to fight) is given to those who are being fought, because they were wronged. And indeed, Allah is competent to give them victory," (Qur'an 22:39). Fight in the way of Allah those who fight you but do not transgress. Indeed, Allah does not like transgressors" and fight them (the transgressors) where ever you meet them and drive them out from where they have driven you out; for persecution is worse than killing... (Qur'an 2:190-191). And fight them until there is no persecution, and religion is professed for Allah. But if they desist, then no hostility is allowed except against the wrongdoers (Qur'an 2:194").

The link between the Jihad concept in Islam and terrorist activities is As a result of terrorist behaviour to piggyback on Islamic concept of jihad to legitimatize their violent actions. Although, Jihad in Islam does not advocate for war against innocent people, terrorist groups have interpreted this religious value totally different from the mainstream teachings (Cinoglu 2010). For instance, according to Islam, taking of one innocent human life is equal to killing of the whole humankind in the universe but to justify their killing activities, their version of Islam needs to be interpreted differently from the mainstream Islam. Terrorist groups such as Al-Shabaab utilize Islamic concept of Jihad and misinterpret to further their own agenda.

\subsection{Effects of perpetrator characteristics on Muslim-Christian relations}

The study revealed that, Al-Shabaab terrorist group have constantly used Islam when staging their attacks. They for instance invoke and quote quranic verses (Maina, 2017) mostly misinterpreted verses on Jihad to advocate for the use of violence against civilians to address their grievances (Hussain and Madhany, 2008). These verses are according to the Muslims scholars (respondents) often taken out of context, to intentionally twist their meaning to advance their illegitimate activities. Consequently resulting to people speculating a relationship between terrorism and Islam. This has in particular made Christians in Kenya believe that Islam is a violent religion (Maina, 2017) and by dint of practicing their religion, Muslims are inherently violent people. This has according to the study's respondents apparently, contributed to suspicion and fear among Christians against Muslims in Kenya. Al-Shabaab terrorist group have constantly been using religious teachings to persuade their militant members to commit acts of terror. Eventually, this results in people speculating a relationship between terror and Islam. The Qur'an is interpreted to suit their cause. This is further as revealed by the respondents of the study aggravated by the AlShabaab's tendency of selectively attacking Christians and their worshiping places. This was clearly demonstrated when the terror group staged a twin attacks of two churches in Garissa on July, 1, 2012, that left about 17 people most of them Christian worshipers dead. Immediately after the churches attacks Hassan Takar, the then spokesman for Al-Shabaab praised the action of the attackers and termed them as Mujahedeen (holy warriors) (Maina, 2016).

Furthermore, Al-Shabaab has been demonizing Christians in Kenya more so in Garissa by often calling them as Kuffars (Arabic term for non-believers) during the attacks giving the impression that their war in Kenya is a religious war. During the 2015 Garissa University attack for instance, the terrorist asked the hostage students to recite verses from the Quran as a way to identify the 
non-Muslim students. The Muslims who recited the Quran were spared while those unable to recite the verses most of whom Christians were singled out and killed (Aguilar 2016).

Al-Shabaab behaviour has also featured a characteristics laden with accusation and grievances against Kenyan government to justify their attacks. The accusations vary from oppression against Muslims in Kenya, foreign troops occupations in Muslims lands to offering support to western powers as Chome (2016) illustrates; "al-Shabaab leaders have circulated a narrative of victimization and alienation of Somali (and Muslim) interests by the Kenyan government and its Western allies. Political debates such as the historically tumultuous relationship between Kenyan Somalis and the Kenyan state are increasingly interpreted using religious image (P.13)'”.

Anselm \& Kunaal (2018), further illustrates how Al-Shabaab exploits grievances and accusations of latent Muslims historical marginalization by the Kenyan Christian majority government and frames them in to religious ideological perspective. Which is then utilized to justify selective attacks and create Muslim-Christian tensions in Kenya as cited below; "Al-Shabaab utilizes Kenya's history of Muslim-Christian tensions in order to mobilize support and justify violence. In doing so, Al-Shabaab uses ideological frames that focus on material grievances in concert with frames using extremist religious interpretations. The resulting violence is often labelled "religious" on the basis of justification and target selection (P.1231)."

In almost all the post 2011 KDF invasion of Somalia, Al-Shabaab claimed their attacks in Garissa and other parts of Kenya, as a retaliatory for Kenya's invasions of Muslim land (Menkhaus,2015). The attacks were therefore a demand of KDF withdrawal from Somalia. During the 2015 Garissa University attack for instance, the militants were very particular in their demand. They told the hostages-students to demand their President (Kenyan president) to withdraw KDF from Somalia and ensure that North Eastern and Garissa belongs to Muslims and not under Kenya's oppressive occupation and that it be given to Somalia. (Jamestown foundation, 2015). The study found that, $\mathrm{KDF}$ presence in Somalia is equated to occupation of Muslim land by a Christian power hence justification for their selective attacks of Christians. These perpetrator characteristics can be explained through the religious utility theory as fronted by Carvalho (2020). For instance, AlShabaab terrorist group use Islam as utility tool to justify their acts and to woo individuals to their activities. They claim that their deeds and ideologies to be the cure of historical marginalization and social economic-inequalities and alienations of Muslim minorities in Kenya. They purport that their cause will provide an alternative solution to the exploitative nature of society that creates alienation. By tying their activities to Islamic religion and selectively targeting the Christians and their worshiping places, suspicions and fear is created between the followers of the two faith. Their constant allusion to the Quran and the concept of Jihad as their bedrock has made Christians in Kenya view Islam as a religion of aggressors instigating anxiety and mistrust in their daily relations with Muslims as will be explained further later in the study.

\subsection{Effects of terrorism on Muslim-Christian relations}

The study established that the Muslim-Christian relations in Garissa county is affected terrorist attacks. Al-Shabaab activities in the area have exploited the religious differences of Kenyans in conducting their attacks which has led to deterioration in Muslim-Christian relations in Garissa. The selective attacks by the terrorists targeted at Christians and their worshiping places has created suspicion and mistrust among the Muslims and Christians in the area. Most of terror attacks have in some way been attributed to Muslims in the area souring their relationship with their Christian counterparts. The respondents mainly Christians observed that, they suspect there is relationship 
between Al-Shabaab's targeted attacks of Christians and the local Muslims in the study area further fueling suspicions between adherents of the two faiths. Chome (2016) in his writings partly shares these views of the study respondent and contends that, Al-Shabaab "recruits were drawn from close family and kinship networks found on both sides of the Kenya-Somalia border in Garissa, including the refugee camps at Dadaab" (P.16). For the Muslims on the other hand, these sentiments are farfetched accusations and just makes the Muslim community in the area more alienated by the Government and gives the security agencies a latitude of profiling them. They argue that Muslims in the area despite being victims of terror attacks are also targeted by government as first suspects of terrorism.

Apparently, the targeted attacks of Christians and their worshiping places by the terrorist group is aimed to divide Kenyans along religious lines. As a result, the terrorist groups aim to instigate religious war between Muslims and Christians in Garissa county and by extension in Kenya. Garissa is predominantly inhabited by Somalis of Sunni Muslims sect. Christians in the county are mainly civil servants NGO workers, and middle-class businessmen and women. Unfortunately, Kenyans and the locals in Garissa seem to have fallen in to the terrorist devious trap and resonating the terrorist narrative of sowing religious intolerance among Kenyans. The harmonious coexistence between the Muslims and the Christians in the area is dying out. The targeted attacks of Christians and their worshiping places by Al-Shabaab have created suspicion between the Muslim and Christians in the study area. Intermingling and freedom of association between the Muslims and Christians in social places have also been greatly affected.

The economic sector has also been adversely affected since many non-Muslims investors have either relocated or lost their investment to attacks. The Al-Shabaab attacks in these businesses especially the hotels such as the attack at Kwa Chege hotel in 2013 is allegedly based on Islamic teachings. For instance, the terrorist justified their attacks on these hotels for selling Islamic prohibited commodities such as alcohol which they claimed was forbidden in Muslim land (Wakube, Nyagah et.al. 2017). Also targeted was joints for watching international football tournaments that was frequented by both local and upcountry youths and partly run by nonMuslims from up country. Additionally, the study revealed that, Al-Shabaab terrorist attacks in Garissa county have prompted an exodus of civil servants, with a disastrous effect on services delivery sector (Haider, 2020). Many non-Muslims civil servants in the county have either sought for transfers or resigned from their jobs for fear of being targeted by the terrorist groups. Large exodus of teachers and medical practitioners in the different parts of Garissa has drastically undermined the quality of education and health care services in Garissa county and other counties of Mandera and Wajir (Haider, 2020). This has further exacerbated the long held grievances of marginalization by the locals in the area in term of lack of service delivery by the Government. As a result of these exodus, learning institution and the health sector in the county become most affected.

The ICG, (2020) argues that the Kenyan government decision of evacuating the teachers from the terrorist prone areas like Garissa is inadvertently playing in to Al-Shabaab's hands; "the [Kenyan government] authorities have evacuated all non-native teachers from the north east. While understandable, given the peril these teachers faced, the policy has brought the school system to a halt and may play into Al-Shabaab's hands by further alienating an already disaffected population. (p.1)” 
The government's actions in response to the teacher's exodus, has also contributed to the already unstable relations between the local Muslims in Garissa against the rest of Christian majority Kenyan communities. The government actions have been viewed as skewed and discriminative against the Muslims minorities and favouring the plights of the Christian majority in the country. Thus, the Kenyan government decision as illustrated by ICG (2020), led to some negative security ramifications; "First, it has created widespread anger in northern Kenya, since residents took it as a further signal that Nairobi does not consider them fully Kenyan. On one hand, Al-Shabaab accuses locals of being too Kenyan; on the other hand, the government sees them as Somali... Secondly, evacuating teaching staff from the north east risks consigning the region's youth to penury or worse... A headmaster at one high school warned that students whose time in school was cut short prematurely would constitute an attractive pool of recruits for Al-Shabaab. (P.5)". In some other cases, some Government officials have committed suicide after receiving letters of their transfers or deployment in Garissa County. For instance, on May 15, 2018 a police officer was reported to have shot himself dead on the spot (Ombati, 2018). This was after the officer was told to report to a police post in Ijara Sub County within Garissa County, which he was not happy with. The post was near to another one that was previously attacked by Al-Shabaab in 2017 (Ombati, 2018).

Further, the terrorist selective attacks on Christians and their worshiping places in Garissa county is buttressing some underlying but already existing racist stereotypes by the local Somalis against the Christian bantus and Nilotes from up country. The stereotypes are mainly because of the locals' social-cultural life and interactions laced with aspects of conservatism. The Somalis in general see themselves smarter and culturally superior to the bantus and the Nilotic communities in Kenya. Some of these stereotypes is evident in the locals Somali language's racist clichés such as the branding of non-locals, mainly of Christian faith as adoomey (slaves), 'abiid (tamed ones) madmadow (the black ones) or Nywele ngumu (hard haired). As a result the interaction between the locals and non-Muslims from up country is characterized with some sort of aloofness and conservatism. These stereotypes coupled with the terrorist selective attacks of Christians are seemingly contributing to suspicions and mistrusts between the local Muslims and Christian from upcountry in the study area. These culturally influenced perceptions together with the conservative suni Muslims of Wahhabi ideologies of the locals (ICG, 2012), is skillfully manipulated by Al-Shabaab to its advantage. Thus forming a foundation that creates rift between the followers of the two faiths.

In relation to the cultural perceptions and its influence on the Muslims-Christian relation Wakube, Nyaga et.al (2017) also reveals that, some locals were not comfortable with the social life such as dressings of the up country non locals. While also alluding to sentiments of the locals Wakube, \& et.al. says; "The arrival of new people with modern customs and dress has also jarred with local culture. "Hizi nguo mnavalia hapa mtavalia kaburini" was a phrase recalled by one local religious leader. It means: "the tight fitting [western] clothes you are wearing now; you will wear in your graves”. (p.7)”.

Wakube, Nyaga et.al. (2017) further claims that the attacks on some churches in Garissa town could partly be attributed to the community's resentments over the conduct of the institutions as illustrated below; "The Somali community believe the targeting of churches was connected to issues between Muslims and Christians. According to a local Catholic priest, the way Christians dressed and held loud prayer services late at night may have been part of the reason why the two churches were attacked in July 2012. Municipal authorities had also allocated land for churches, 
and this had created resentment among Muslims (who have to buy the land for mosques to be built). (p.13)”.

ICG, (2012) also points out that, the conservative nature of the Somali communities in accepting foreign cultures could partly be informing Al-Shabaab targeted attacks; "North Eastern Province is increasingly conservative. In 2010, a number of sheikhs called for a TV ban. Small bands of informal moral police try to shut down bars, ban cigarette sales and enforce dress codes. Since the intervention in Somalia, there have been sometimes deadly grenade attacks on bars in Garissa and Mandera (p.9)”.

The targeted attacks of Christians especially the April 2015, Garissa University attack has also resonated some spillover effect and revenge from Christians against Muslims in some other places in Kenya. This was evident when buses and travelers from Garissa and other parts of northern regions plying the Garissa- Nairobi road were blocked and attacked with stones at Mwingi town. The angry public largely of the Christian faiths accused the Somali and the Muslim communities for the selective killing of the Christian students. Some passengers were as a result of this attacks by the angry public injured and it was after the police had intervened the passengers continued with their journey.

The Government security agencies overreaction when countering terror attacks according to respondents, seemingly patronages the deteriorating Muslim-Christian relation in Garissa county. According to the study respondents the security personnel in Garissa county has been treating all Muslims and particularly the local Somalis as suspects in their investigations of terror related cases. The locals are in many cases profiled as terror suspects by the security personnel and also discriminated at roadblocks and security checkpoints. This has further inculcated a feeling of otherness among the local Muslims and consequently serving Al-Shabaab's narratives.

Menkahus (2015) also reiterates similar sentiments as the respondents above and argues that; "More importantly, the historical track record of state security abuses of the populations in northern Kenya - now at least partially documented and verified by the Kenyan government itself - has served as a powerful source of alienation and grievances. Both during the period of the state of emergency (1963-1992) and since the rise of counter-insurgency operations against Al-Shabaab (2011-), Kenyan security forces have constituted one of the main sources of insecurity for local populations, rather than a source of protection. The impulse to engage in collective punishment against entire Somali communities has contributed to this problem (P.28)".

Apparently, the security forces tendency of leniency for the non-local Christians and high hardness against the locals Muslims in executing terrorism related cases, is sowing hate and mistrust among the adherents of the two faiths. The locals are as a result getting radicalized or becoming indifferent to the terrorist selective attacks of Christians and their worshiping places. It also paves the way for Al-Shabaab to exploit these complaints of injustices and mistreatments of the locals by security agencies as an entry point to the locals while presenting their cause as an alternative solution against these injustices. Also, some Christian Government security officials use the selective attacks by Al-Shabaab to generalize and profile the local Muslims in the study area as potential terror suspects. They also misuse their authority to harass and mishandle Muslims in the area. This prejudiced behaviour of the security officials is apparently tainting the relations of the locals with the security apparatus as well as antagonizing them against the Christian public. These discriminatory conduct is backed by ignorance of some 
Christians about the teachings of Islam and Muslims code of conduct leading to generalization and branding of innocent Muslims as terrorist. The security services overreaction was evident on November 19, 2012 after three KDF officers from Somalia mission were killed by AlShabaab militant in Garissa town. Following this incident, the security personnel killed and injured several innocent locals and set ablaze private business premises as captured in the Kenya National Assembly Committee Hansard (2012).

Such reactions by the security personnel did not only kill the relation between the Muslims and the Christians but also makes the area residents view the Government and its security machineries as their enemy. This kills the cooperation of the locals in the fight against terror groups. Additionally, the study established that, the Muslims in Garissa and the other former North Eastern province counties of Wajir and Mandera lament that they have long been neglected by the "Christian" led postcolonial subsequent regimes partly due to their faith and affiliation with Somalia. The difficulty in identifying and differentiating Kenyan Somalis and other Somali nationalities has been noted as being used by some Christians mainly Government officials to generalize the locals as foreigners from Somalia. This is further aided by the fact that many Kenyan Somalis don't have national identity cards that would have otherwise proofed their nationality. They are as a result subjected to a lot bureaucratic measure to get services from Government offices. This is further complicated by the terrorism menace that has arguably to some extent been associated with Somalis only especially by some sections of security personnel.

All Somalis regardless of their nationalities speak the same language, profess the same religion of Islam and have similarities in their physical appearances. Thus posing a challenge to the respective Government officials in the departments of immigration and security to identify the genuine Kenyan Somalis from Somalis of other nationalities. The problem is further complicated when a Kenyan Somalis don't have the national identification card (ID) and decides to get one with the subsequent bureaucracies and vetting processes. All the same the issue of Somali identity has been a source of discontent among the Somalis in Garissa who feel discriminated on their ethnic and religious background as compared to their Christian counterparts who are not subjected to similar stringent measures. This has in turn created a feeling of 'otherness' among the Muslims in Garissa which subsequently aides the terrorist to exploit such fault lines and creates bad blood between the Christians and Muslims in Garissa.

The terrorist selective attacks in Garissa and other parts of Kenya has exacerbated some longheld perceptions of some Christian sections in Kenya. They allege that Muslims in Kenya have long term agenda of creating and converting Kenya in to an Islamic (sharia) state. Such claims were evident in the 2005 and 2010 constitution making process in Kenya particularly on the aspects of entrenching the khadi court in the Kenyan law. As pointed out by Maina (2017), the issue of the khadi courts has been surrounded by a lot of controversy and debates within a cross section of the Kenyan populace, both Muslims and Christians, clergy and lay people, politicians and a cross section of scholars and legal experts. The question of khadi court in the constitution is said to have strained the Muslims-Christians relations during the 2010 constitution referendum.

The issue of the khadi courts was one of the main reasons for majority of Christians' opposition to the 2010 draft constitution of Kenya. They viewed this as giving Muslims superior status in relation to other religions and more importantly in relation to the Christian. Maina (2017) observes that, the debate on the court has produced extreme forces on either side of Muslim- 
Christian divide. Consequently, the ultimate entrenchment of the Islamic court in the Kenya's 2010 promulgated new constitution has spawned a sense of "Islamophobia" in Kenya (Maina,2017). With the increasing terrorism in the country the issue of khadi court is likely to be resurrected as observed by ICG, (2012). "Many Christian groups feel aggrieved. Intercommunal relations are frayed, and the fissures opened by the ill-tempered contest have widened. With intercommunal tensions likely to worsen due to the growing fear of jihadi terrorism, the potential for violence is real. (P.13)".

Even so, the persistent terrorist targeted attacks on Christians and their worshiping places and the resultant deterioration of Muslim-Christian relations notwithstanding, there has been instances of solidarity in response to terrorist activities in Garissa. Some sections of the Muslim locals have stood with their Christian counterparts in Garissa in the light of selective terror attacks. This was evident during the 2015 Garissa University attack, when some Muslim mothers come out and hid the Christian student who managed to escape the siege in their houses. They gave them clothes, food and were later reunited with their families. Likewise, following the targeted attacks on churches in Garissa town, some sections of the local Muslims also volunteered to guard Christians churches on Sundays as they performed their worshiping rituals.

\subsection{Conclusions and Recommendations}

\subsection{Conclusion}

The study concludes that Islam provides a clear teaching on Jihad which is not equivalent to war or terrorism and killing of innocent people. Jihad in Islam is mainly concerned with the person's internal struggle with his/her soul against evil deeds referred to as major Jihad and that Jihad is not synonymous with terrorism. There is also lessor Jihad which entails Muslims engagement in physical war mainly for defensive purposes against oppressions. More specifically, the teaching of Islam is that: Jihad does not advocate for war against innocent people, Jihad embodies holiness and sanctity, every Muslim is obliged to do good deeds, and Jihad rallies for peace. Terror perpetrators' characteristics of using Islamic religious teachings, presenting of myriads of accusations against targets and grievances of marginalization by Christian powers against Muslim to justify their attacks affects Muslims-Christian's relations in Garissa. Al-Shabaab terrorist group use Islam to justify their attacks as was evident during the Garissa university attack where AlShabaab claimed their attack as Jihad and that were only interested with non-Muslim targets. Further, Al-Shabaab has also been levelling accusation against Kenyan government to justify their attacks. KDF presence and demand for its withdrawal, oppression against Muslim minorities in Kenya has defined their Justification for attacks against Kenyans. They used these grievances to justify selective attacks against Christians and their worshiping places which has consequently greatly contributed to deteriorating relations of Muslims and Christians in Garissa county.

Selective terrorist attacks on Christians and their worshiping places, has contributed to the deteriorating Muslim-Christian relations in Garissa County, Kenya. As a result of the terrorist tendency of targeted attacks of non-local Christians in the study area, suspicions and mistrust dented the Muslim-Christian relation in Garissa county. Most of the terror attacks have in some way been attributed to Muslims in the area souring their relationship with their Christian counterparts in Garissa. That terrorist attacks in the county has paralyzed the learning and health sector with mass exodus of staffs in these institutions. The government's actions in response to these exodus, has also contributed to the already dented Muslim-Christian relations in Garissa. The government actions of evacuating the civil servants have been viewed as skewed and 
discriminative against the Muslims minorities and favouring the plights of the Christian majority in the country. Further, some latent and long held racist notions and stereotypes among the locals against Christians non-locals, coupled with terrorist selective attacks of Christians is fueling suspicions and mistrusts among the adherents of the two faiths. This is also skillfully manipulated by Al-Shabaab to its advantage further worsening the Muslim-Christian relations in the area. Apparently, some incidences of spillover effects resulting from targeted terror attacks of Christians has been observed in some other parts of the country where Christians attacked locals from northern Kenya travelling to Nairobi.

The Government security agencies reactions in countering terror attacks seemingly aids the deterioration of Muslim-Christian relation in the county. The locals are in many cases profiled as terror suspects by the security personnel and also discriminated at roadblocks and security checkpoints. This has further inculcated a feeling of otherness among the local Muslims and consequently serving Al-Shabaab's narratives. However, the targeted attacks and the resultant suspicions and mistrust between the Muslim and Christians notwithstanding, the Muslims and Christians in the study area have portrayed some instances of unity in dealing with terrorism menace in Garissa.

\subsection{Recommendations}

This study recommends that the government counter-terrorism approach should be devoid of discrimination and targeting of Muslim minority and Somali ethnic group in the country. The government should also sensitize and mobilize the support of the Somali community in Garissa in an effort to improve the relationship between the locals and the security personnel in the area so as to have a common stand in the fight against terrorism. The study also recommends for the withdrawal of KDF from Somalia as continued presence is likely to justify for more attacks by AlShabaab in the country. Muslim leaders and scholars should carry out awareness campaigns about proper teachings of Islam on Jihad and war. Mosques and other social places should be used to demystify the notion that Jihad is intended to attack innocent people. Proper references to the Qur'an should be made and selective application of the Qur'an should be discouraged. The campaigns should target youths and other persons with high risk of joining extremist groups. Interreligious dialogue should also be initiated by the religious leaders of both the Muslims and Christians in Garissa County. The teaching of Islam on Jihad from the quranic text as well Christian's bible teachings of war should be exchanged. This should be aimed at enlightening the followers of the two faiths on the religions perspective of war and peace so as to dispel terrorist misinterpretations of religious texts. The county Government of Garissa should form an interreligious reconciliatory committee to address issues of suspicions and mistrust that fuels the differences between Muslims and Christians. The civil society in conjunction with Government and local community members should embark on social integration programs that aim at restoring and maintaining mutual relationship between Christians and Muslims. The programs should focus on forming Muslim-Christian caucus that will be used to support the social interaction between Christians and Muslims.

\section{References}


Aguilar M. (2016) Muslim-State Relations in Kenya. In: Mason R. (eds) Muslim Minority-State Relations. The Modern Muslim World. Palgrave Macmillan, New York. https://doi.org/10.1007/978-1-137-52605-2_7

Aktan H. (2006). Acts of Terror and Suicide Attacks in the Light of the Qur'an and the Sunna.in Ergun Capan (Eds). An Islamic Perspective: Terror and suicide attacks. New Jersey: The Light, Inc.

Albayrak, I. (2010). The Juxtaposition of Islam and Violence in Hunt, R.A and Aslandogan, Y.A. (edis.) Muslim Citizens of the Globalized world: Contribution of the Gulen Movement. Texas, USA: Tughra Books

Alio, M. S. (2015). Kenyan Christian-Muslim Relations: Bridging Factors and Persisting Challenges. International Journal of Education and Research, 3, 111-128.

Aljazeera (2014, June 16). Al-Shabaab claims responsibility for attack on Kenya town. AlJazeeraAmerica. Retreived from: http://america.aljazeera.com/articles/2014/6/16/deadly-attack- kenyacoast.html accessed on 19 November, 2016

Anangwe, A. (2004). International Terrorism and East African sub-regionalism: Developing Sub-regional Tourism Industry in the Face of War. African Journal of International Affairs, 7(1\&2), 81-97

Ansalem, R. \& Kunaal, S. (2018). The Determinants of Religious Radicalization: Evidence from Kenya, Journal of Conflict Resolution, ISSN 1552-8766, Sage, Thousand Oaks, CA, Vol. 62, Iss. 6, pp. 1229-1261. Retrieved from, http://dx.doi.org/10.1177/0022002716678986 accessed on $18^{\text {th }}$ November,2021

Arce, D., and Sandler, T. (2003). Terrorism and Game Theory: Simulating \& Gaming, 34(3), 319337.

Berkley Center (2017). Faith and Development in Focus: Kenya. World Faiths Development Dialogue(WFDD). George Town University

Borum, R. (2004). Psychology of terrorism. Tampa: University of South Florida.

Bukay, D. (2006). The Religious Foundations of Suicide Bombings: Islamist Ideology Middle East Quarterly.V.3, pp. 27-36.

Cannon, B. J. (2016) Terrorists, Geopolitics and Kenya's Proposed Border Wall with Somalia. Journal of Terrorism Research, V.7 (2), pp.23-37. DOI: http://doi.org/10.15664/jtr.123

Carvalho, J-P. (2020). Religion and Terrorism: The Religious Utility Hypothesis. Irvine: University of California,

Chome, N. (2016). Violent Extremism and clan dynamics in Kenya, Peace works series. Issue no. 123. U.S Institute of Peace, Washington, DC

Cinoglu, H. (2010). Sociological Understanding of the relationship between terrorism and religion. International Journal of Human Sciences Vol.7 iss.2. Retrieved from http://www.insanbilimleri.com/en 
Daily Nation (2014, March,19). Explosion kills six in Eastleigh suburbs. Daily Nation. Retrieved from: http://www.nation.co.ke/news/blast-kills -six-in-Eastleigh/-/105/

Enders, W., \& Sandler, T. (1995). Terrorism: Theory and applications. In K. Hartley \& T. Sandler (Eds.), Handbook of Defence Economics, Vol. 1 (pp. 213-249). Amsterdam: NorthHolland.

Gulen. M. F. (2010). Muhamad the Messenger of God (Ali Unal trans.). New Jersey: Tughra Books

Gupta, S. K. \& Rangi, R. (2014). Research methodology. Methods, tools and techniques ( $4^{\text {th }}$ ed.). New Delhi: Kalyan Publishers.

Haider, H. (2020). Conflict analysis of North Eastern Kenya. K4D Emerging Issues Report 36. Brighton, UK: Institute of Development Studies.

Hansard, (2012) Report of the Joint Committee Investigating the Matter of the Adverse Security Situation, Loss of Property, Loss of Lives of Security Personnel and Civilians in Garissa and Eastleigh Towns, and the Baragoi Environs Nov. 23 -Dec. 18, 2012.The Hansard, Kenya National Assembly

Hargis, G. (2012). Muslim-Christian Relations in Kenya: The Importance of Interfaith PeaceBuilding for Development. (Honours program thesis) University of Arizona. Retrieved from; https://repository.arizona.edu/handle/10150/243963 on 16 October 2021

Hassan A. B. (2013). Concept of Jihad and its nature in Islam IOSR Journal of Humanities and Social Science (IOSR-JHSS), 8(1), 25-32.

Holbrook, D. and Horgan, J. (2019), Terrorism and Ideology: Cracking the Nut.

Perspectives on Terrorism Volume 13, Issue 6

Hussain R. and Madhany N. (2008) Reformulating the Battle of Ideas: Understanding the

Role of Islam in Counterterrorism Policy Analysis Paper Number 13, August 2008

ICG. (2020,). How to Shield Education from Al-Shabaab in Kenya's North East. Crisis

Group Africa Briefing $N^{\circ} 159$, 22 July 2020 Nairobi/Brussels. Retrieved from www.crisisgroup.org on 23, December 2021.

ICG (2012). Kenyan Somali Islamist Radicalisation. Crisis Group Africa Briefing No.85, 25 January 2012 Nairobi/Brussels

Kingsley, O. (2010). Religion and Terrorism: A Socio-Historical Re-Consideration. Journal of Alternative Perspectives in the Social Sciences, 2(2), 550-576.

Kurucan, E. (2013) Jihad: What Is It and What Is It Not? The Fountain Magazine Issue 96 / November - December 2013. Retrieved from www.fountainmagazine.com $22^{\text {nd }}$ November, 2016

Lapan, H., \& Sandler, T. (1988). To bargain or not to bargain: That is the question. American Economic Review, 78, (2), 16-20.

Lind, J., Mutahi, P., \& Oosterom, M. (2015). Tangled ties: Al-Shabaab and political volatility in Kenya. IDS Evidence Report N. 130, Addressing and Mitigating Violence. Brighton. 
Retrieved from;

http://opendocs.ids.ac.uk/opendocs/bitstream/handle/123456789/6018/

ER130_TangledTiesAlShabaabandPoliticalVolatilityinKenya. pdf?sequence $=526$

Maina, N.K(2017). A History of Christian-Muslim Relations in Kenya, 1963-2015. In G.L., Heath, and D.K., Taurus, (eds.). Christian Response to Terrorism: The Kenya Experience. Mc Master Divinity College Press: Pickwick Publications, Eugene, Oregon pp.12-32

Mazrui, A. (2006). Islam Between Globalization and Counterterrorism. USA: Africa

World Press.

Mahmoud, A. H. (2008). Seeking Citizenship on the Border: Kenya Somalis, the

Uncertainty of Belonging, and Public Sphere Interactions. Talk presented at CODESRIA $12^{\text {th }}$ General Assembly. Yaoundé, Cameroon.

Moywaywa, K. C. (2018). Management of Religious Conflicts in Kenya: Challenges and opportunities. international Journal of Education and Research Vol.6. Issue 1. Pp 129142

Menkhaus, K. (2015). Conflict Assessment/ Northern Kenya and Somaliland. Research for Danish Demining Group (DDG). March, 2014

Naado, H.O. (2013, November,11) Clerics' Killings Fuel Religious Conflict. The Star. Retrieved from; http://www.the-star.co.ke/news/article-143100/clerics-killings-fuel-religiousconflict. on 11 September, 2015

Ndzovu, H. J. (2014) Muslims in Kenyan Politics: Political Involvement, Marginalization and Minority Status. Evanston., North-western University Press

Noorani, A. G. (2002). Islam \& Jihad: prejudice versus reality. New York: Zed Books

Nyongesa, M. (2017). Are Land Disputes Responsible for Terrorism in Kenya? Evidence from Mpeketoni Attacks. Journal of African Democracy and Development vol.1, issue2, pp. 33-51.

Ombati, C. (2018) Policeman shoot himself dead over transfer in Garissa. Standard Newspaper May 162018.

Open Society Foundation (2013). We're Tired of Taking You to the Court: Human Rights Abuses by Kenya's Anti-Terrorism Police Unit. Report by Open Society Foundation. Available at; www.opensocietyfoundations.org. accessed on $1^{\text {st }}$ September, 2015

Schmid A.P(2011). The definition of terrorism in A.P Schmid (eds), The Routledge, Handbook of Terrorism Research. Routledge. USA pp.39-99

Shah Z. (2009). Jihad and Terrorism: A Comparative Study. the Dialogue, IV (4), 527-554

Standard, (2012, Nov.21) MPs protest as ministers differ over Garissa KDF operation. The Standard newspaper Retrieved from: https://www.standardmedia.co.ke on 23 December 2021 
Standard (2013, January,5) Two Killed in Garissa grenade attack. Standard Newspaper. Retrieved from https://www.standardmedia.co.ke on 23 December 2021

Star. (2012, July 2.) 17 Killed in Garissa Attack. The Star. Retrieved from http://www.thestar.co.ke/news/article-12099/17-killed-garissa-attack

Star, (2012, August 7). Chronology of Terrorist attacks in Kenya. The Star newspaper. Retrieved from http://www.the-star.co.ke

Star, (2013 April, 20). Nine killed in Garissa shooting. The Star. Retrieved from http://www.thestar.co.ke/news/article-117540/nine-killed-garissa-shooting

Start (2013). Al-Shabaab Attack on Westgate Mall in Kenya. START Background Report September 2013

Chome, N. (2016). Violent Extremism and clan dynamics in Kenya, Peace works series. Issue no. 123. U.S Institute of Peace, Washington, DC

Wakube C., Nyagah, T., James. M.\& Larry A. (2017) Inside Kenya's war on terror: breaking the cycle of violence in Garissa. London: Safer world. Retrieved from https://static1.squarespace.com/static/58921b4b6b8f5bd75e20af7e/t/597f105886e6c0 3d8024f59b/1501499494866/breaking-the-cycle-of-violence-in-garissa-v2.pdf accessed on 19 November, 2018

This is an open-access article published and distributed under the terms and conditions

of the cc) Creative Commons Attribution 4.0 International License of United Statesunless otherwise stated. Access, citation and distribution of this article is allowed with full recognition of the authors and the source. Authors seeking to publish with an Internationally Peer Reviewed Journals should consider https://www.ijcab.org/ by writing to the Editor at editor@iicab.org or submitting online at https://iournals.iicab.org/iournals/index.php. The articles must be quality and meet originality test. 